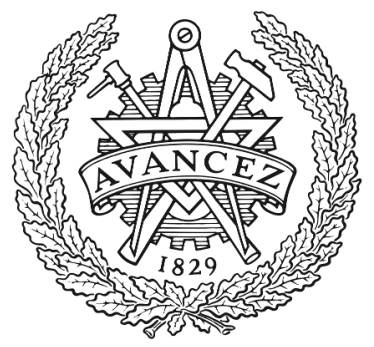

CHALMERS

UNIVERSITY OF TECHNOLOGY

\title{
The Metamorphosis of Katniss Everdeen: The Hunger Games, Myth, and Femininity
}

Downloaded from: https://research.chalmers.se, 2023-04-26 08:03 UTC

Citation for the original published paper (version of record):

Strong Hansen, K. (2015). The Metamorphosis of Katniss Everdeen: The Hunger Games, Myth, and Femininity. Children's Literature Association Quarterly, 40(2): 161-178.

http://dx.doi.org/10.1353/chq.2015.0020

N.B. When citing this work, cite the original published paper. 


\title{
The Metamorphosis of Katniss Everdeen: The Hunger Games, Myth, and Femininity
}

\author{
Kathryn Strong Hansen
}

\begin{abstract}
Many myths tell stories of transformation and change, as does Suzanne Collins's coming-of-age trilogy The Hunger Games (2008-10). This threebook bildungsroman tells the story of one young woman's transformation from child to woman, and from poverty-stricken hunter to revolutionary symbol. The trilogy's original book covers depict this change with an icon: The Hunger Games' cover displays the heroine's pin, a gold bird in a circle; Catching Fire's cover shows a similar bird raising its wings as if coming to life; and Mockingjay shows that bird extending its wings to break the confines of the circle. The trilogy's plot also focuses on transformation, and its heroine, Katniss Everdeen, finds herself similarly (if metaphorically) transformed into a bird, reminiscent of the metamorphoses prevalent in ancient myths. Collins has identified some of the specific mythic influences on The Hunger Games, most notably Theseus and the Minotaur, saying that "I was a Greek mythology fanatic as a child" (Grossman, "Gladiator Game"). The trilogy's invocation of Greco-Roman myths connects Katniss's dystopian future to our historic past, but it also emphasizes the violence and brutality that hallmark those myths. Moreover, the presence of mythic elements points to the dangers of reproducing beliefs inherited from the past. I argue that in addition to the trilogy explicitly employing mythic elements, Katniss implicitly displays many of the traits of heroines from Greek myth during her formation of her gender identity. Specifically, the figures of Artemis and Philomela exist within Collins's trilogy as potential paths of femininity for Katniss to follow, and she tries both paths in an attempt to construct her gender identity. ${ }^{1}$ The two figures provide Katniss with ways of navigating a dictatorial patriarchy, culminating in her ultimate rejection of both mythic characters to create a form of femininity that allows her to break free from her past and to change her society.

While Katniss displays elements of both Artemis's and Philomela's personalities, she does not perfectly align with either. For instance, while Artemis is a
\end{abstract}

Kathryn Strong Hansen is an assistant professor of English at The Citadel, the Military College of South Carolina. Her research focuses on intersections of literature, gender, and visual culture. 
goddess, Katniss is mortal, and her life is in peril throughout Collins's trilogy. Artemis is also Apollo's sister and hunting partner, but while Katniss has established a hunting partnership with fellow District 12 citizen Gale Hawthorne, the possibility of romance between the two makes clear that they do not have a sibling-like relationship. ${ }^{2}$ In fact, Katniss's late father seems to fill the role of Apollo because he hunted with her and displayed Apollo-like skill with music. Likewise, the Philomela myth is also a less-than-perfect match for Katniss's story. While Katniss at times displays traits that link her with Philomela, I argue below that she also shares traits with Philomela's sister Procne and nephew Itys, other characters in the myth. The imperfect alignment between Katniss and these mythic figures suggests that she does not effectively embody either mythic woman's form of femininity. Ultimately, this misalignment helps her to reject both of these roles, calling into question just how seamlessly an inherited form of femininity can fit any young woman.

Even so, when the narrative begins Katniss strongly evokes the figure of Artemis because of their shared status as bow-wielding hunters. Artemis's bow is her hallmark, with Hesiod's "Hymn XXVII" to Artemis describing her as a "pure maiden, shooter of stags, who delights in archery" (453). Callimachus's "Hymn 3: To Artemis" addresses her impulse to use her bow to correct others' behavior, identifying Artemis with her bow when he asks, "And how many times, Goddess, / did you test your silver bow?” (lines 161-62). Her bow also suggests her power as a sort of vigilante who seeks justice, or what she decides is justice. But soon, she points it at the wrongs of humanity in order to punish unjust behavior:

a city of criminals

was your target now, people

guilty over and over, of sins

against each other, sins against strangers. Fools,

they have your wrath to contend with now, a bitter

dough to swallow. (165-70)

Similarly, Katniss uses her bow to combat injustice. Her country's government prefers its districts' citizens to be hungry and impoverished, the better to keep them weak and unable to rebel. From the time of her father's death in a coal mine explosion, Katniss works to fight this injustice done to her family. Katha Pollitt describes Katniss as displaying "moral centeredness" and points to her habit of thinking "about fairness and justice," all of which aligns her with Artemis (10). Yet Artemis's concept of justice often looks a great deal like vengeance, and perhaps the most famous story about her involves her transformation of the great hunter Actaeon into a stag simply for accidentally having seen her bathing in the forest. He is then chased and killed by his own hunting dogs. The Actaeon story suggests that justice for Artemis is not only a very malleable concept, but also one that she interprets from self-interest rather than from a detached desire for fairness. ${ }^{3}$ Katniss's decisions are often similarly motivated 
by personal advantage. When she initially tries to understand fellow District 12 tribute Peeta's actions, for instance, she refuses to see him as simply kind. "A kind Peeta Mellark," Katniss notes, "is far more dangerous to me than an unkind one. Kind people have a way of working their way inside me and rooting there. And I can't let Peeta do this" (Games 49). While this view is pragmatic given that she and Peeta will soon be competing for survival, the speed with which she decides on the plan of having as little to do with him as possible demonstrates her tendency to make decisions based on her own self-interest, echoing Artemis's goddess-like emphasis on self.

Katniss's identity as a hunter dovetails neatly with Artemis's, in no small part because they both prefer to spend their time in nature. As Monica Cyrino observes, Artemis is "depicted in myth as generally rejecting the company of humans and shunning heavily populated urban spaces: [she] favored small groups of attendants and companion animals in the wilderness" (378). Katniss's fundamental identity as a hunter forms the core of her identity when the trilogy starts, and her focus on providing for her family means that she, too, favors the forest. From her father, Katniss learns much about nature, and, like Artemis, she feels most at home there. Her father teaches her to find the edible roots of the katniss plant, for which she is named, telling her how her namesake (and by extension, her identity) can sustain her: "As long as you can find yourself, you'll never starve" (Games 52). This metaphorical act of finding herself through her father's guidance finds potent expression in the many pieces of her identity that come from him; indeed, Katniss's gender identity has been more strongly shaped by stereotypical masculinity than by traditional femininity.

Katniss also shares Artemis's fabled virginity, with her romantic and sexual innocence a running theme throughout the books. Susan Guettel Cole notes that Artemis "had to remain permanently a parthenos [virgin] and biologically a girl, for she could protect girls, brides, and adult women from the dangers of reproduction only if she herself was immune to its disabilities" (209). When her former hunting partner Gale tells Katniss he loves her, this shocks her, and she admits, "I never see these things coming" (Fire 97), having previously asserted that "There's never been anything romantic" between them (Games 10). Her inability to recognize Gale's romantic inclinations indicates her sexual innocence, and her correlation with Artemis is deepened by the many instances of her discomfort with expressions of sexuality. For instance, when she meets Finnick, a tribute in Katniss's second Hunger Games, she admits that she is "feeling uncomfortable at [his] closeness, especially since he's got so much bare skin exposed" (Fire 208). Peeta explains to her why Finnick and others work to make her uncomfortable: "It's like when you wouldn't look at me naked in the arena even though I was half dead," he informs her. "You're so ... pure" (Fire 216). Peeta elevates Katniss's innocence to a lofty status through his use of the word "pure," labeling her lack of interest in sex a noble, even goddess-like trait.

Protection of children and pregnant women is another of Artemis's attributes. Callimachus's "Hymn 3: To Artemis" includes the goddess's admission 
that the Fates made her the helper of women in labor "the moment I was born, because / my mother felt no pain / in birth or pregnancy, but brought me / from her body without effort" (33-35). Artemis is also said to watch over those in her favor, guarding their childhoods so that "Only bodies full of years / are carried to their funerals" (179-80). Katniss displays similar devotion to children in establishing herself as the protector of her younger sister Prim, having taken on the status of a secondary mother to her because of their own mother's immobilizing depression following her widowhood. Her fierce desire to protect her sister is the initial plot catalyst, leading Katniss to volunteer to take Prim's place in the Hunger Games. Her desire to protect children also leads her to ally herself with Rue, a young competitor in Katniss's first Games. Katniss's Artemisian instinct to help others, especially children, will later lead Hunger Games survivor Johanna Mason to despise her for her "defender-of-the-helpless act. Only it isn't an act" (Mockingjay 219). As Johanna recognizes, Katniss's desire to help the powerless, children in particular, is a notable part of her identity.

Katniss's initial alignment with many of Artemis's characteristics complicates her femininity. Not only does Artemis display nontraditional femininity, but many of Katniss's Artemisian traits also connect her with her deceased father. For instance, he made her bow and taught her to hunt, so when she takes over as family provider after his death, she takes on a more stereotypically masculine role. But her Artemisian traits result more from her circumstances than from her own choices. Katniss's gender identity at the trilogy's beginning has been irremediably shaped by the Capitol, the tyrannical dictatorship that rules Panem, the futuristic fractured United States of America, effectively enslaving the citizens in the districts that support it with agriculture and raw materials for manufacturing. The death of Katniss's father in the coal mine explosion when she is eleven, and her mother's paralyzing grief and resulting neglect, combine to force Katniss into the more traditionally masculine role of family provider. Her initial display of Artemisian gender attributes is thus as much a product of the Capitol as is her later gender image, and the reader must wait until the end of the trilogy to witness Katniss making her own choice about what kind of femininity she wants.

The trilogy's first novel amplifies Katniss's alignment with her father by depicting her as rejecting her mother, including the latter's traditional femininity. Katniss establishes that she and her father both had the physical coloring typical of the laborers in District 12, namely, "straight black hair, olive skin, ... gray eyes," and that this coloration separates her from her female family members, who have the "light hair and blue eyes" of the district's merchant class (Games 8). Katniss repeatedly constructs herself as separate from her mother and Prim, and though she feels a strong attachment to her family, her self-appointed role as their protector allows her to see herself as superior to them. ${ }^{4}$ Katniss's rejection of traditional femininity indicates that she believes that the traits she chose or inherited from her father mark her as better than her mother and sister. She rejects any similarity to her mother, as evidenced when she dresses for 
the reaping ceremony that will select District 12's participants for the Hunger Games. Katniss's mother "has laid out one of her own lovely dresses for me," and in it, Prim tells her, "You look beautiful" (Games 15). Katniss's response, "And nothing like myself," distances her from the feminine attribute of beauty and the stereotypically feminine interest in clothing. But it also distances her from her mother, whose clothes trigger the compliment that Prim pays her. The more Katniss displays stereotypically feminine traits, the more she sees herself as like her mother, and therefore as weak and delicate. She equates this feminine vulnerability with an increased likelihood of dying.

Katniss's Artemisian form of femininity, then, involves a devaluing of feminine stereotypes. Another popular young adult series helps to demonstrate this aspect of Artemis's character. In Rick Riordan's Percy Jackson and the Olympians series (2000-2009), the protagonist learns that he is a son of Poseidon, and his adventures place him in contact with the gods. At one point, Percy meets Artemis, who surrounds herself with a cult of young female followers called the Hunters of Artemis. In describing the Hunters, Artemis emphasizes the importance of their youth, because she serves as patron to young women before they go "astray." Artemis presents stereotypical teenaged femininity pejoratively, because to go "astray" is to "Grow up. Become smitten with boys. Become silly, preoccupied, insecure. Forget themselves" (38). Here, as with Katniss, Artemisian gender identity rejects stereotypical femininity because it supposedly lessens the strength of young women, diminishing rather than enhancing their identities. In The Hunger Games, Katniss finds herself forced to endure some of the trappings of conventional femininity, such as romance and elaborate clothes, as part of her public persona. Over the course of the trilogy, this more canonically feminine gender identity increasingly aligns Katniss with Philomela, a young woman whose desirable femininity is transmuted into vengeance.

Several elements of the Philomela myth appear in the Hunger Games trilogy. Philomela's story of repeated suffering culminates in revenge, a motivating force that Katniss finds emotionally appealing but ultimately unsustainable. This myth begins when Philomela's sister Procne marries Tereus, king of Thrace. Ovid describes how Tereus becomes enraptured with Philomela's beauty, the appealing quality of her clothing prefiguring the power of the textiles she will later use: "In entered Philomela, richly robed / In gorgeous finery ... The sight of her set Tereus' heart ablaze" (“Tereus, Procne, and Philomela” lines 452-53). Tereus abducts Philomela, imprisoning and raping her. To prevent her from telling anyone what he has done, he cuts her tongue out. Philomela, however, informs Procne about Tereus's crimes by weaving her story into a tapestry and sending it to her. The two sisters secure their revenge when they kill Itys, Procne's son by Tereus, cooking and serving the child's body to him. Enraged when he learns what has happened, Tereus chases the sisters, who pray to the gods for escape. To save them, the gods turn Tereus, Procne, and Philomela into birds. In effect, the aftermath of the sisters' vengeance is so overwhelming that it denies all participants their humanity. The ending of this story shows 
what is at stake if Katniss embraces the path of Philomela: vengeance spawning retaliatory vengeance until the gods themselves intervene. But in Collins's world of Panem, there are no gods to step in, so there is no mechanism in place to stop what Collins has called a "cycle of violence that seems impossible for us to break out of" (Grossman, "Writing Stories").

Though the Philomela myth is evident in The Hunger Games, it does not neatly map onto Katniss's story. In both narratives, children suffer for the actions of their forefathers. Just as Itys dies in punishment for Tereus's abducting, raping, and silencing of Philomela, the Capitol creates the Hunger Games to make the progeny of the districts' rebels-including Katniss-suffer in payment for their parents' transgressions. These tales also share a strong bond of sisterhood, with Procne demonstrating a fierce sisterly love for Philomela. Similarly, Katniss's desire to protect her sister Prim leads her to volunteer as tribute, and her grief at Prim's death leads her to behave as callously as Procne toward the end of Mockingjay when Katniss approves the establishment of a Hunger Games that uses the Capitol's children. Procne destroys a seemingly essential part of her femininity-her maternal protectiveness - in her quest for revenge, and Katniss displays a similarly chilling disregard for children in her vote in favor of one more Hunger Games. But the Philomela myth appears in Collins's trilogy in a fragmented state, involving many characters besides Katniss. The fact that all of the Hunger Games participants are children links them all to Itys, and as the books progress it becomes clear that all of Panem is potentially subject to the kind of Philomelan identity rape that tributes experience in the Games arenas. In part, this point explains why the Philomela identity does not fit Katniss well, since it is a sort of one-size-fits-all myth for almost everyone in Panem. But it appeals to Katniss because it is a narrative that invokes the suffering of everyone she knows, which fuels her desire for vengeance on behalf of all who suffer in Panem.

Another powerful element from the Philomela myth that The Hunger Games employs is the use of textiles to speak when silence is enforced for those who suffer. According to Kathryn Kruger, dress, femininity, and mythology enjoy a close relationship, since "weaving constitutes one of the first signifying practices that recorded the world's ancient myths and symbols" (33). Dress's cultural alignment with conventional femininity creates difficulty for Katniss, since dress is part of the feminine tradition she has largely rejected. The multivalent meanings of Katniss's clothing subvert the Capitol's dominant order, but they also pose a danger for her because she does not always understand her clothing's potential meanings. Here, unlike in the Philomela myth, the one who encodes messages into textiles is not the central female character. Her stylist and mentor share that role. Yet Katniss must navigate her clothing's codes, complex ones because, as Malcolm Barnard writes, clothing and fashion "may be understood as weapons and defenses used by the different groups that go to make up a social order, a social hierarchy, in achieving, challenging or sustaining positions of dominance and supremacy" (38). In helping to elevate Katniss to the level 
of political symbol, dress becomes a weapon against the Capitol, but her lack of participation in the selection of her clothes compromises Katniss's power throughout the trilogy. Consequently, her dress tends to place her on the path of Philomela, a role that requires Katniss to display the markers of a kind of femininity that does not come naturally to her.

While Philomela's use of textiles shows her to be an active participant in her own fate, Katniss's engagement with them shows her as a passive enactor of others' plans for her. As Amy L. Montz acknowledges, "the tributes seem to have no control over their roles within the Games, or over their stylizing in the opening ceremonies" (140). Employing the elements of conventional femininity to survive does not make Katniss enjoy them, but she suffers through this beautification process because she realizes that passivity can be a means to an end: clothing and style exert great power in the Capitol and beyond. Her stylist Cinna is well aware of this power, as he is the trilogy's most adroit user of clothing to create an image. Cinna uses clothing as a covert form of opposition to the Capitol. In this way, he also takes on a Philomela-like role, complicating Katniss's alignment with the mythic sufferer. In his first work as Katniss's stylist, Cinna attires her in artificial flames for her initial pre-Games appearance. In so doing, he begins the process of turning a young woman into a symbol of revolution, while he simultaneously tries to protect her by limiting her knowledge of what he is doing. That he yokes her with the idea of fire allows the districts to associate her with the metaphorically incendiary spirit of revolution and vengeance.

Because it will help hide revolutionary intentions, Cinna works to create Katniss's public persona as that of a stereotypically feminine girl, a difficult role for her because it is not one of her own choosing. A few days after their first public presentation, the tributes appear on a talk show, interviewed by a popular Capitol celebrity. Katniss here plays the role of a dress-obsessed girl, registering as nonthreatening to her competitors as well as to those in power in the Capitol. This version of femininity is far from the identity of family provider and protector that Katniss experienced prior to becoming a tribute, and formulating this public persona is the result of a painstaking struggle. Before the talk show, Katniss works for hours with her mentor Haymitch to develop a culturally acceptable personality that will endear her to the sponsors who might donate fabulous sums of money to deliver her gifts of medicine, food, or other necessities in the Games arena. In trying to train her for her interview, Haymitch makes clear that Katniss's authentic self is too surly and private to attract sponsors, so she scrambles to assemble a persona that others will find attractive. But Katniss fails in her attempts to be anything but herself: "By the end of the session, I am no one at all" (Games 118). Rather than acknowledging her own identity as valid, she sees it as empty of any content. Her view results from the fundamental disconnect between the traits that she feels are intrinsic to her and those that the audience expects of her. Katniss does not even consider the strategy of acting weak to make her opponents disregard her, a strategy of 
which she is aware because she mentions it early in the first book. She has seen the false veneer of weakness in previous Hunger Games victor Johanna Mason, who "seemed like such a sniveling, cowardly fool that no one bothered about her until there were only a handful of contestants left. It turned out that she could kill viciously. Pretty clever, the way she played it" (Games 41). Despite finding this strategy "pretty clever," Katniss takes the goddess-like stance of disdaining to appear as anything less than formidable. When she watches the interview of fellow tribute Thresh, she wishes she could be like him and behave aggressively. She explains why she believes this choice is unavailable to her: "If only I was his size, I could get away with sullen and hostile and it would be just fine! I bet half the sponsors are at least considering him" (Games 126). Though Katniss deflects the idea of any difference between her and Thresh onto issues of size, another salient difference between the two is sex. Thresh can make the choice to be sullen because he is male, and traditional masculinity allows for the masking of emotion. Katniss prefers this persona, but her advisors disallow it because it is not acceptably feminine.

One of the ways in which a young woman's identity can register positively with the Panem audience is through her sexual desirability, and Katniss's fabricated romance with Peeta Mellark helps give shape to the narrative that will save their lives as well as inspire a revolution. After Peeta uses his preGames interview to confess his love for Katniss, her response is anger. She asks Haymitch whether it was his idea to turn her "into some kind of fool in front of the entire country," and she complains that Peeta "made me look weak" (Games 135). Katniss here reveals her distaste for the role of desirable woman, which is born of her belief that conventional femininity equates with weakness. In the myth of Philomela, desirability brings violence as well as identity erasure to Philomela, so it is no surprise that its invocation here disturbs Katniss. Just as Philomela's beauty attracts Tereus's unwanted attention, Katniss's narrative of desirability contributes to the other tributes' targeting of her. In neither case does the woman do anything blameworthy, but both suffer nonetheless for their conventional femininity. Yet the role of passionate lover is necessary to excuse Katniss's threatening to kill herself and Peeta at the end of their first Hunger Games, and therefore, as Holly Blackford explains, "compulsory heterosexuality ... is literally thrust upon her as a means of survival" (39). Peeta continues to use feminine stereotypes to protect Katniss when, just before they both enter the arena for the Quarter Quell, he publicly lies that she is pregnant. By creating the stories that she is part of a star-crossed love pair and that she is about to be a mother, Peeta heightens public sympathy and helps viewers of the Games see Katniss as a heroic victim behind whom they should throw their support. She may bristle at these markers of what she perceives as weakness, but she does not oppose the stereotypically feminine associations because they protect her life. Again, Katniss is forced to perpetuate ideas about her femininity that she does not choose. 
However, the trilogy also shows readers that it is Katniss's authentic choices, not a false persona, to which people most enthusiastically respond. In Mockingjay, when the District 13 rebels discuss how best to use Katniss in their carefully scripted anti-Capitol propaganda pieces, they seek to improve her poor performance. After a committee of rebels recalls moments when Katniss made them feel something real, they realize that these moments were all the result of her own impulses, moments when "no one told her what to do or say" (Mockingjay 75). These "real" moments testify to Katniss's impulses toward active caring, an element of her preferred brand of femininity. Here the trilogy suggests that Katniss needs to construct her own identity instead of assuming extant forms of femininity that are imperfect, messy role models for her. For instance, when she takes the twelve-year-old tribute Rue as her ally in her first Hunger Games, she acts partly from a desire for companionship. But Katniss reveals another motivation in her choice to join forces with Rue when she says, "Why not admit it? She reminds me of Prim" (Games 201). This "real" moment allows a glimpse into Katniss's emotions. Her natural inclination to care for Rue gives rise to an anti-Capitol fury upon Rue's death, a "fury against the cruelty, the injustice they inflict upon us" (Games 236). Her moments of authenticity do not last, however, because she has little power to make her own choices free from the Capitol's influence. So her behavior again bends toward a scripted path, here the path of Artemis, but this form of femininity is not free from troubling elements.

Like that capricious goddess, Katniss finds controlling her desire for vengeance difficult, and these feelings often result from her wish for justice. She is angry at the Capitol for reaping her sister, frustrated that the only way to save Prim was to volunteer in her place (and thus lose her own ability to hunt for and protect her), and ready to find ways to secure vengeance against the Capitol for putting them in this situation. So when Rue reminds her so strongly of Prim, Katniss's protective instincts are triggered. When Rue dies, she experiences the same hopelessness she felt when Prim was reaped. Katniss's desire for justice finds expression in her silent protest, a memorial of flowers that she places upon Rue's corpse. Katniss's first response to Rue's death is a desire for vengeance, and she laments that there is no way to take revenge on the Capitol. But she then remembers what Peeta told her before the Games began: "I keep wishing I could think of a way to . . to show the Capitol they don't own me. That I'm more than just a piece in their Games.' And for the first time, I understand what he means" (Games 236; emphasis in original). The flowers allow Katniss to make a statement against the barbarity of killing young children, and also defy the divisions the Capitol wants to perpetuate among the districts. Moreover, the flowers are of the Artemisian natural world, allowing Katniss to situate herself in opposition to President Snow because he always wears a rose that is genetically enhanced to have an unnaturally strong odor. For Katniss, the flowers announce a message, which she articulates in the language of vengeance: "Something happened when I was holding Rue's hand, watching 
the life drain out of her. Now I am determined to avenge her, to make her loss unforgettable, and I can only do that by winning and making myself unforgettable" (Games 242). In this moment, as in many of her moments of vengeance, Katniss bridges the worlds of Artemis and Philomela. She does so not only by employing stereotypical femininity-using flowers to send a message that inspires others to help her in her vengeance, much as Philomela does with her tapestry message to Procne-but also by demonstrating her wish for justice and loyalty to an innocent girl, much as Artemis does in her role as protector of the young and vulnerable.

Far more prevalent than Katniss's statements, however, are her silences. These silences further align her with Philomela, whose brutal silencing by Tereus incites the myth's cycle of vengeance. In addition, the presence of the Avoxes, who have had their tongues removed and have been enslaved by the Capitol as punishment for treason, is an oblique reference to the Philomela myth. While the Avoxes are the ones who have lost the physical ability to speak, their presence underscores how Katniss frequently restrains her speech. Silence in the arena is practical: it allows Katniss to hunt food and avoid detection by the other tributes. Yet she also chooses to censor herself on many topics so that she can protect friends, family, and herself. In the Games arena, she will not mention the illegal hunting that gave her enough money to buy her sister Prim a goat, nor will she say that the death of District 11 tribute Thresh is "murder," since the Capitol would punish such judgmental wording (Games 268, 308). Were these her only silences, they would invoke the protective Artemis rather than the vengeful Philomela, since these silences place others' lives and well-being as paramount and are active choices made by Katniss herself.

But Katniss does not merely silence herself; others render her silent as well, reinforcing her subjection to the Capitol's power. These power mechanisms inhibit her from speaking, and, by extension, from articulating a selfhood of her own choosing. When Prim's name is called at the District 12 reaping ceremony, Katniss is initially "unable to speak" (Games 21). She also calls herself "Avox mute" when she sees Peeta beaten by the Capitol after warning District 13 of an impending attack (Mockingjay 137), and she becomes a "mental, rather than physical, Avox" after being badly burned in the explosion that kills Prim (Mockingjay 350). Katniss's silences keep her powerless against the seeming omnipotence of the Capitol, much as Philomela's silence leaves her seemingly powerless against Tereus, and they signal moments of self-doubt. So despite Katniss's hunting prowess, mental stamina, and physical resilience, she spends much of the trilogy as a pawn in the Capitol's plans to keep the districts under its command. As Susan Shau Ming Tan has noted, "Articulation in Panem is denied - there is no safe or sanctioned space for any expressions of self or identity" (57). Katniss spends most of the trilogy being someone she does not want to be, and her discomfort with and resistance to this more conventionally feminine identity is evidence that it is not what she prefers. 
Katniss's forced persona changes constitute a kind of rape perpetrated upon her identity by the Capitol and by the rebels, pushing her into the Philomela-like role that erases her voice. Her performance in the rebels' scripted "propos," or anti-Capitol propaganda pieces, serves as a silencing of her own voice by making her read someone else's words. By the time she is allowed to be herself in the propos, she has already become largely incapable of thoughtful reflection on her own identity. The rebel PR team can only obtain compelling, usable footage of Katniss when she responds to an environment without thinking. Katniss's gender identity, then, has been confused, first by her attempts to demonstrate conventional heteronormative femininity in her first Hunger Games, next by her impulse to seem tough yet romantically tender in the Quarter Quell, and last by her forced status as an attractive icon who seduces Panem's district citizens into rebellion. After the reshaping of her femininity to respond to others' cultural scripts, Katniss slips back onto the path of Philomela largely because that myth's escalating number of sufferers corresponds to the widespread suffering in Panem, and she feels the desire for vengeance against the Capitol on behalf of all of them. The Philomela path's emphasis on vengeance also appeals to that part of her already existing Artemisian gender traits that seeks a justice that looks a great deal like a goddess's vengeance.

Like Philomela, Katniss seethes with righteous indignation over the violence and silencing that she has been forced to undergo. Her initial embodiment of outright rebellion, rather than implied subversion, comes again at the hands of Cinna, who designs her costumes when she is forced to participate in the Games a second time in Catching Fire. As before, celebrity Caesar Flickerman interviews the tributes prior to the beginning of the Games, and Cinna signals to her to twirl. This time her gown burns away to reveal a feathered dress. Cinna has clothed her as a mockingjay, the bird on the brooch that Katniss brought with her as her token in the first Games. The brooch is a gift from Madge, the daughter of District 12's mayor, who tells Katniss that it used to belong to her aunt. ${ }^{5}$ Katniss discovers more about the pin's history in preparing for the Quarter Quell, when she learns that Madge's aunt was a tribute in the previous one. Katniss admits that the pin "means something completely different now that I know that its former owner was Madge's aunt, Maysilee Donner, a tribute who was murdered in the arena" (Fire 196-97). While Katniss does not elaborate on exactly what that "something completely different" is, her use of the term "murdered" suggests that Maysilee has become another person whose death Katniss wants to avenge. This realization is part of a gendered transformation. When Katniss first sees the brooch, she associates it with her father despite it being a gift from her female friend. He had liked mockingjays because the birds would always repeat his songs back to him. Katniss therefore initially chooses to see the pin as "like having a piece of my father with me, protecting me," instead of seeing it as a sign of feminine strength (Games 43-44). The "something completely different" that she later sees in the pin is 
also a growing awareness of feminine strength, something that develops over the remainder of the trilogy.

The mockingjay as Katniss's symbol is an inheritance from a suffering woman, much as her stereotypically feminine identity markers are an inheritance from the mythological subjection of Philomela. Being forced into displaying traditional femininity triggers a Philomela-like quest for vengeance in Katniss. In her televised interview before the Quarter Quell, she twirls away her gown to reveal a mockingjay costume underneath it. Katniss reports, "I can tell [Caesar] knows that the mockingjay isn't just my token. That it's come to symbolize so much more. That what will be seen as a flashy costume change in the Capitol is resonating in an entirely different way throughout the districts" (Fire 253). Because Katniss defied the Gamemakers at the end of her first Games, threatening to eat poisonous nightlock berries unless both she and Peeta were declared unprecedented co-victors, she became a symbol of the possible power of the districts over the Capitol. Though double suicide looks like her goal to viewers, Katniss here only mimics the actions of a starry-eyed girl driven to despair at the thought of losing her lover. The Games have always had a victor, and Katniss reasons that without one, "the whole thing would blow up in the Gamemakers' faces. They'd have failed the Capitol. Might possibly even be executed, slowly and painfully while the cameras broadcast it to every screen in the country" (Games 344). Her stratagem stems from vengeance rather than from love for Peeta or a desire for justice. She relishes the quandary that she has put the Gamemakers in, as witnessed by her lingering over the description of their potential execution. Now, the citizens of the districts see the fire from which the Mockingjay is born as an invitation to rebellion. Her embrace of the Mockingjay role pushes her further down the Philomela path that seeks vengeance at all costs.

The rape theme from the Philomela story shifts in The Hunger Games into one of identity rape, with Katniss realizing that the Capitol is responsible for irrevocably changing her personality. Her risking of her and Peeta's lives uses the Capitol's tools against them: the invasive cameras that strip her of her privacy also ensure an audience that would descry her martyrdom, and the Capitol's murderous Games would lose meaning without a victor. The success of her nightlock gambit helps to transform Katniss from an Artemisian hunter girl uneasy with assuming the mantle of conventional femininity into a Philomela-like entity willing to use traditional feminine tropes, like that of the love-obsessed girl, to her advantage. Katniss's narrative also increasingly aligns her with Philomela's in that both stories highlight a human's transformation into a bird. Katniss's transformation is symbolic rather than literal, but her Mockingjay status threatens her grasp on her humanity, just as Philomela's transformation literally ends hers. Despite the power that Katniss appears to embody as the Mockingjay, this role requires that she accept the need for projecting a feminine type instead of her real identity. Katniss recognizes how little her own personality will matter if she accepts this role, and she writes 
that what the rebels want "is for me to truly take on the role they designed for $m e$. The symbol of the revolution. The Mockingjay... They have a whole team of people to make me over, dress me, write my speeches, orchestrate my appearances - as if that doesn't sound horribly familiar - and all I have to do is play my part" (Mockingjay 10-11; emphasis mine). Overtly, her role in District 13 's rebellion reminds her of her powerlessness under the regime of President Snow in the Capitol.

In fact, the only reason the rebels rescued her from the Quarter Quell Games arena is that they value her importance as a symbol: "We had to save you because you're the mockingjay, Katniss,' says Plutarch. 'While you live, the revolution lives'” (Fire 386). The role of inspirational warrior invokes Artemis, because during battles, Cole remarks, Artemis "inspired soldiers at critical moments - moments sometimes distinguished by the appearance of the goddess herself. A dramatic epiphany of the goddess, accompanied by a flash of light, revealed the moment of crisis or turning point of battle" (189). When Katniss finally agrees to act as the Mockingjay, the rebels require her to display the trappings of traditional heteronormative femininity, like Philomela, while acting as an Artemisian inspiration to bring more rebels into the fold. This mixing of different forms of femininity creates the fertile ground in which Katniss's self-doubt, anxiety, and stress grow, and shapes her personality into one that is difficult if not downright unpleasant.

Katniss experiences one more transformation before she will conclusively reshape the forms of femininity that she has been employing. Shortly before she is scheduled to kill Snow, she burrows into "a wardrobe full of silken things." She notes, "Swathed in silk, I feel like a caterpillar in a cocoon awaiting metamorphosis," and explains that she is "unable to emerge until I have transformed into something of beauty." This encounter with clothing seems to make her aware of how her outward image has actually denied her agency: "When the guards finally locate me, I'm sitting on the floor of the wardrobe, tangled in silk, screaming my head off. I fight them at first, until they convince me they're trying to help, peel away the choking garments, and escort me back to my room" (Mockingjay 363-64). Just as clothing propelled her into the Philomela role that sought vengeance against the Capitol, here it limits her breathing and inspires her to wish for change back to a more "beautiful" self, a persona that jibes with her true self rather than a burdensome one that satisfies others' expectations. Bow in hand, she faces Snow as his executioner, yet she chooses to launch her arrow at Panem's new president, the rebel leader Alma Coin. ${ }^{6}$ Throughout Catching Fire, Katniss is urged to remember who the "real enemy" is. As Sarah Seltzer has explained, "The enemy is a system that pits people against each other, not the people you are pitted against. Turn your anger away from your competitors to the powers that be. This is a feminist message if there ever was one, and a collectivist one" ("Revolution"). While her fellow rebels have identified the Capitol as "the powers that be," Katniss has realized that Coin's perpetuation of forms of cruelty inherited from the Capitol makes 
her the real enemy. Katniss's embrace of change for Panem is also an endorsement of transformation for herself. In killing Coin, Katniss chooses to reject the existing political structure of cruelty for Panem, much as she has decided to reject the inherited forms of femininity with which she has been struggling.

Part of the importance of this choice is that it is just that: her choice. No longer does Katniss follow anyone else's path for her. Instead, she actively decides to kill President Coin rather than indulge her desire for revenge against Snow, fueled by Coin's encouragement. Here, Katniss follows neither Artemis's nor Philomela's path, both of which use vengeance as justification for their actions. No longer acting only from motives of vengeance, Katniss realizes that Coin's presidency will not effect real change in Panem, as Coin makes clear in the moments before Snow's planned execution. In that meeting, Coin calls together the remaining Hunger Games victors to make them vote on whether to hold one last Games. The point of using children from the Capitol, she tells them, is to satisfy the districts' "need for vengeance" while not further diminishing the country's perilously low population (Mockingjay 369). When it is her turn to vote, Katniss feels hopeless in the face of what seems like an inevitable push toward vengeance, toward the path of Philomela and Procne that uses children to make one's enemies suffer:

Was it like this then? Seventy-five years or so ago? Did a group of people sit around and cast their votes on initiating the Hunger Games? Was there dissent? Did someone make a case for mercy that was beaten down by the calls for the deaths of the districts' children? ... All those people I loved, dead, and we are discussing the next Hunger Games in an attempt to avoid wasting life. Nothing has changed. Nothing will ever change now. (Mockingjay 370)

In this moment, Katniss sees no option other than allowing history to repeat itself, and so she votes in favor of staging another Hunger Games. In contrast, in the last moments before Katniss is to execute Snow, she realizes that killing him would simply perpetuate the existing cycle, and thus finds the option that she did not see during the victors' vote. By killing Coin rather than Snow, Katniss not only rejects Coin's avowed emphasis on vengeance, but also rejects and repairs her own embrace of it. While incarcerated and awaiting sentencing for the assassination, one day Katniss suddenly begins to sing. She literally finds her voice once she has resolutely rejected the vengeance path of Philomela, who is incapable of speech.

In addition, the epilogue to Mockingjay reinforces Katniss's ultimate rejection of Artemisian femininity. Collins has pointed to the role of the future in the interpretation of her trilogy: "I think people respond to dystopian stories because they're ways of acting out anxieties that we have and fears that we have about the future" (Grossman, "Love Story"). In showing that it is possible to break out of these patterns of expected behavior, Collins has expressed hopefulness for the future. That this moment occurs in an epilogue is significant, as Mike Cadden explains, and its importance for providing emotional satisfaction to readers 
has much to do with who those readers are. "The distance between beginning and ending is measured by a sense of cause and effect," Cadden writes, yet "the distance between the end and epilogue in children's fantasy is measured by the adult's desire that the reader be comforted at all literary costs" (355). But he acknowledges that the epilogue to the Hunger Games trilogy performs work that moves beyond the comforting of child audiences. While this comfort may come at a literary cost, changing readers' perceptions of Katniss's strong warrior personality, the epilogue works in service of the larger theme of transformation.

The epilogue's clarification of Katniss's willingness to have children indicates true difference in the Panem of the future. Katniss had long vowed never to be a mother, because she refused to give innocents into the power of the Capitol. Since she has decided to have children, readers know that Panem has truly changed. ${ }^{7}$ The shift away from the Capitol's power that the rebellion secures also contributes to this sense of change. Throughout the trilogy, the Capitol's associations with ancient Rome are evident. From the Latin names of those who live there (President Coriolanus Snow; stylists Cinna, Portia, Flavius, and Octavia; announcer Claudius Templesmith; and so on) to the gladiatorial-style combat in the Hunger Games, the similarities between Rome and the Capitol are manifest. Katniss's choice to reject both Artemisian and Philomelan femininity is a break with ancient myth as well as with Panem's past. Katniss changes Panem into a place in which children are no longer pawns, as Itys was in the Philomela myth, and she also changes her own gender identity so that unlike Artemis, she no longer rejects motherhood. Katniss admits that it took "five, ten, fifteen years" for her to agree to have children, and that she did so because "Peeta wanted them so badly" (Mockingjay 389). Though Katniss resists romance throughout the trilogy, faking the role of romantic ingénue for survival, she comes to accept the fulfillment that she experiences with Peeta. His nonstereotypical masculinity-his association with "the dandelion in the spring" (Mockingjay 388), his artistic ability, his role as a baker rather than a hunter-complements her nontraditional femininity, ending the trilogy with the sense that Katniss's last transformation allows her to enjoy traditional femininity without having to be the only one who demonstrates feminine traits.

Seltzer summarizes The Hunger Games by explaining that the books encourage readers to ask "whether they're the ones who should work to change things for the better, and consider how much they'd be willing to sacrifice to see justice done" ("Hunger Pangs" 42). Katniss must sacrifice her negative view of femininity in order to break away from the repressions of selfhood enforced by the Capitol. While the epilogue could be read as a conservative reaffirmation of traditional femininity, the trilogy's oblique use of the figures of Philomela and Artemis suggests another possibility. The protagonist's transformations from Katniss to victor to Mockingjay are effected through key elements in the Philomela myth, such as clothing and silence, which keep her locked in a desire for revenge. Once Katniss rejects vengeance, she is able to accept the fact that aspects of conventionally feminine roles appeal to her. Her early belief that 
only traditionally male characteristics can aid in survival initially causes her to reject all conventional femininity. The trilogy's uses of the Philomela myth give Katniss an awareness of the power of some forms of femininity, but on their own, these silence-enforcing, textile-based elements cannot provide the transformation that she needs. Katniss therefore rejects the Philomelan form of femininity. Yet she also rejects the Artemisian insistence on remaining unmarried and childless, accepting that she is neither a superior and solitary goddess, nor that she is only fighting for herself, as if her own life were a never-ending Hunger Games. Consequently, in becoming a mother, Katniss demonstrates her faith that the world has changed enough to be a safe place for children. Through Katniss's ultimate rejection of the Philomelan and Artemisian roles, Collins's trilogy indicates the importance of young women breaking with history to make their own personae, demonstrating that femininity need not simply replicate the forms that have previously existed.

\section{Notes}

1. Following the lead of Katha Pollitt, Sarah Seltzer, and others, I use the Greek name Artemis rather than that of the Roman goddess Diana. As William Smith has explained, "Romans identified their goddess Diana with the Greek Artemis, and at a comparatively early time they transferred to their own goddess all the peculiar features of the Greek Artemis" (376). Therefore, the similarity between these two goddesses makes them difficult to differentiate when they are invoked rather than directly named (as I am arguing is the case in Collins's trilogy).

2. Katniss and Gale are at one point said to be cousins, but this is a ruse to make their long-standing relationship not appear to threaten Katniss's constructed romance with fellow District 12 tribute Peeta Mellark: "It wouldn't do, what with the romance I was playing out in the arena, to have my best friend be Gale. He was too handsome, too male" (Fire 12).

3. The Actaeon story can be found in several texts, perhaps the most notable one being Book III of Ovid's Metamorphoses. Ovid, using the goddess's Roman name, writes that "not until so many countless wounds / Had drained away his lifeblood, was the wrath, / It's said, of chaste Diana satisfied. / As the tale spread views varied; some believed / Diana's violence unjust; some praised it, / As proper to her chaste virginity" ("Diana and Acteon" lines 246-51).

4. Vera Woloshyn, Nancy Taber, and Laura Lane describe Katniss before her participation in the Hunger Games as "an unflawed young woman" (157). Yet Katniss's disdain for her mother and her feelings of superiority to Prim suggest that she is not an ideal role model when the trilogy begins, and that a transformation is necessary to repair flaws to her character that arise from living in the corrupt world that the Capitol has created.

5. The film version of The Hunger Games changes the origins of the mockingjay pin, depicting Katniss as choosing the pin from a vendor in District 12's trading market as a gift for Prim. Thus the film ultimately has Katniss wear the pin as an emblem of her sister's affection. However, while this revision would change the kind of feminine 
influence represented by the pin, I confine my remarks in this essay to the textual rather than the filmic version of Collins's story.

6. Though Amanda Firestone writes that Katniss "rarely, if ever, uses her agency ... [even when] she appears to have the ability to do so" (217), this is one unambiguous instance in which Katniss does exert agency. Firestone's observation that "There's a tremendous difference between activity and agency" (215) is true of Katniss's other choices, but in killing Coin she clearly uses activity in the service of personal agency.

7. Some critics see the epilogue as evidence that Katniss's power has diminished. Katherine R. Broad, for example, argues that "The series' conclusion in an epic heroine defaulting to a safe, stable, and highly insular heterosexual reproductive union-a union so much like the social and sexual status quo of our own world — raises questions about just what has been transformed by Katniss's harrowing fight" (125). While it would be a refreshing change to have a non-gender-normative heroine, here the transformation in Katniss's views on having children signals that her world has become safer. This point aligns with Cadden's idea of reassurance as paramount in epilogues to works with child or young adult audiences.

\section{Works Cited}

Barnard, Malcolm. Fashion as Communication. London: Routledge, 1996.

Blackford, Holly. "The Games People Play: Speculative Childhood and Virtual Culture from Ender to Hunger." Critical Insights: Contemporary Speculative Fiction. Ed. M. Keith Booker. Ipswich, MA: Salem, 2013. 31-50.

Broad, Katherine R. “The Dandelion in the Spring': Utopia as Romance in Suzanne Collins's The Hunger Games Trilogy." Contemporary Dystopian Fiction for Young Adults: Brave New Teenagers. Ed. Balaka Basu, Katherine R. Broad, and Carrie Hintz. New York: Routledge, 2013. 117-30.

Cadden, Mike. “All Is Well: The Epilogue in Children's Fantasy Fiction.” Narrative 20.3 (2012): 343-56.

Callimachus. "Hymn 3: To Artemis." The Poems of Callimachus. Trans. Frank Nisetich. Oxford: Oxford UP, 2001.27-37.

Cole, Susan Guettel. Landscapes, Gender, and Ritual Space: The Ancient Greek Experience. Berkeley: U of California P, 2004.

Collins, Suzanne. Catching Fire. New York: Scholastic, 2009.

. The Hunger Games. New York: Scholastic, 2008.

. Mockingjay. New York: Scholastic, 2010.

Cyrino, Monica S. "Bows and Eros: Hunt as Seduction in the Homeric Hymn to Aphrodite." Arethusa 46.3 (2013): 375-93.

Firestone, Amanda. "Apples to Oranges: The Heroines in Twilight and The Hunger Games." Pharr and Clark, 209-18.

Grossman, Lev. “'Come for the Love Story, Stay for the War': A Conversation with Suzanne Collins and Francis Lawrence." Time 22 Nov. 2013.

The Metamorphosis of Katniss Everdeen: The Hunger Games, Myth, and Femininity 
. "I Was Destined to Write a Gladiator Game': A Conversation with Suzanne Collins and Francis Lawrence." Time 20 Nov. 2013.

_. "Writing 'War-Appropriate' Stories for Kids: A Conversation with Suzanne Collins and Francis Lawrence." Time 19 Nov. 2013.

Hesiod. The Homeric Hymns and Homerica. Trans. Hugh G. Evelyn-White. Cambridge, MA: Harvard UP, 1936.

Kruger, Kathryn Sullivan. Weaving the Word: The Metaphorics of Weaving and Female Textual Production. London: Associated UP, 2001.

Montz, Amy L. "Costuming the Resistance: The Female Spectacle of Rebellion." Pharr and Clark, 139-47.

Ovid. Metamorphoses. Trans. A. D. Melville. Oxford: Oxford UP, 1986.

Pharr, Mary F., and Leisa A. Clark, eds. Of Bread, Blood and The Hunger Games: Critical Essays on the Suzanne Collins Trilogy. Jefferson, NC: McFarland, 2012.

Pollitt, Katha. “The Hunger Games' Feral Feminism.” The Nation 294.17 (23 Apr. 2012): 10.

Riordan, Rick. Percy Jackson and the Olympians: The Titan's Curse (Book III). New York: Hyperion, 2007.

Seltzer, Sarah. “The Hunger Games' Gender Role Revolution.” RH Reality Check. 12 Dec. 2013.

_. "Hunger Pangs: Hunting for the Perfect Heroine." Bitch Magazine: Feminist Response to Pop Culture 51 (2011): 39-42.

Smith, William. A Dictionary of Greek and Roman Biography and Mythology. Boston: Little, Brown and Co., 1867. Housed online at the University of Michigan $<$ http:// name.umdl.umich.edu/ACL3129.0001.001>.

Tan, Susan Shau Ming. "Burn with Us: Sacrificing Childhood in The Hunger Games." The Lion and the Unicorn 37.1 (2013): 54-73.

Woloshyn, Vera, Nancy Taber, and Laura Lane. "Discourses of Masculinity and Femininity in The Hunger Games: 'Scarred,' 'Bloody,' and 'Stunning.'” International Journal of Social Science Studies 1.1 (2013): 150-60. 